\title{
Modeling of Energy Requirements for Broiler Production in Kurdistan Region, Iraq
}

\section{Mudhafar K. Abdullah*1, Ahmed M. Abdulrahman Al-Khdri², Merkhan Mah- di $^{2}$ and Shimal Omar ${ }^{1}$}

${ }^{1}$ Scientific Research Center, College of Agriculture, University of Duhok, Iraq

${ }^{2}$ Animal Production Department, College of Agriculture, University of Duhok, Iraq

*Corresponding author: mudhafar.kareem@uod.ca

\begin{abstract}
:
This study was conducted to determine the energy requirements of broiler production in Duhok at Kurdistan region. To this study, the data were collected and questionnaire performed record during both summer and winter season in 11 farms, which covered the entire distracts of Duhok province and the average number of surveyed farms was 11240 birds. The data were compared statically by standard deviation and correlation coefficient. The average of meat broiler production in Duhok was $2634 \mathrm{~kg}\left(1000\right.$ birds $\left.^{-1}\right)$ and average of input energy was177,368 $\mathrm{Mj}\left(100\right.$ birds $\left.^{-1}\right)$. The results were showed that the fuel recorded $54.5 \%$ and $54.6 \%$ which was the highest value for input energy during both summer and winter season, respectively. The lowest value was observed with labor elements. The high positive correlation observed between labor and electricity was (0.45). Broiler production in Kurdistan region consumed high diesel fuel and energy as well as low economic income of famer. To this effect, more assist and support from local governments is essential to improve the productivity and quality.
\end{abstract}

Keyword: Broiler, energy requirements, Duhok.

Received on: 8/12/2014

Accepted for publication on: 1/1/2015

Referees: Prof. Mohamed E. Mohamed

Prof. Mohamed A. Abd El Latef 


\section{1-Introduction:}

Energy requirements are a driving force on broiler production at both national and international levels. Energy is the core of all human activities. Kurdistan region is one of the promising growth areas in Middle East. The knowledge of energy consumption of broiler process is essential to estimate and determine the high area of consumption (Alrwis and Francis, 2003; Heidaria, 2011). The final goal of any energy management scheme is to optimize the energy component of the production costs. Furthermore, energetic analysis can give the ability to compare each processing unit as well as to find best alter line production for the producer (Adonis et al.,2009). Energy can be converted from one form to another with energy conversion techniques. Also, energy can be representing in many figures and illustrates (Mariano, 2007). Control ventilation system of poultry building and building design are one the greatest concerns, require more efficient and intensive for poultry production system is essential of greater yield (Toghyani, 2011).Therefore, some studies have been performed with the objective to determine the energy requirements of poultry production at Middle East countries. The input energy significantly decreased when broiler poultry size increased from 10,000 to 28,000 at tropical area. Also, the energy index significantly affect with increasing of building capacity (QotbiAli et al., 2011). Another study in Iran applied solar energy to produce poultry building ventilation regarding to the abundant of solar received their (Esmaei et al., 2013). Modeling of energy saving of whole building is the simulation model obtained $4.7 \%$ dropping of electricity consumption, while gas consumption increase about 6.9\% (Ojo, 2003; Yiqun Pan, 2009). The presence of suitable infrastructures, such as building, fence around the perimeter of the buildings and ventilation system, spicily at region with very diverse climate change is necessary for broiler brad frames (Santos and Falconi, 2007; Kizilaslan, 2009; Lima, et al., 2011). Total input energy of 1000 broiler bird production in Iran was found to be $186,885.87 \mathrm{MJ}$, whereas the output energy was 27,461.21 MJ (Heidari et al, 2011). Broiler modern poultry farms obviously use mechanical ventilation systems. This mechanical ventilation requires an amount of electric energy as well as a high level of investment in technology. (Atilgan and Hayati, 2006; Eliseo Bustamante, 2013). The objectives of this study were to determine the energy element requirements of broiler production and to identify the sufficient from insufficient components of energy uses at Duhok province in Kurdistan Region.

\section{2-Material and Methods:}

\section{2-1-1: Study and Location}

In this study, the data were collected from eleven farms of broiler in twelve locations which covering the province of Duhok. The total Area of the farms are $6,553 \mathrm{~km}^{2}$ and the total of broilers are about 1,300,000. This province is situated 900 meter above the sea level. Duhok is one of coldest province in Kurdistan region and the temperature distribution as well as humidity of 2013 (Table 1). The local government was measured the amount of broiler meat for person regarding to the local production, by $13.7 \mathrm{Kg} /$ year at 2013 (Table 2).

\section{2-1-2: Data collection:}


The data collected for energy analysis of broiler production was conducted in Kurdistan region, 11 farms at Duhok includes (Semel, Shekhan, Kujur, Zawita, Sarsink, Mangeashike, Kura, Bardarash, Zakho, Amedi and Akre) which included material of this study. The data collected individual during both summer and winter season, that represent the whole year of 2013. The input data includes chick, fuel (diesel fuel \#2), electricity (national electricity), feed (broiler nutrition's at each farms) and labor (the employer at each farm), while the output energy includes broiler meat and manure The farmer at these locations marketing their production in average age of (50 days) and the specification of each farm can be seen from Table (3). The energy requirements are calculated per 1000 bird $^{-1}$ as at measure in standard international method.

Table (1): Temperature degrees and Humidity in Duhok at 2013.

\begin{tabular}{|c|c|c|c|c|}
\hline Months & $\begin{array}{c}\text { Minimum } \\
{ }^{\circ} \mathbf{C}\end{array}$ & $\begin{array}{c}\text { Maximum } \\
{ }^{\circ} \mathbf{C}\end{array}$ & $\begin{array}{c}\text { Average } \\
{ }^{\circ} \mathbf{C}\end{array}$ & $\begin{array}{c}\text { Humidity } \\
\mathbf{\%}\end{array}$ \\
\hline December & 2.8 & 12.0 & 7.4 & 16 \\
\hline November & 10.9 & 20.4 & 15.65 & 17 \\
\hline October & 14.5 & 27.0 & 20.75 & 20 \\
\hline September & 19.9 & 34.2 & 27.05 & 24 \\
\hline August & 24.5 & 39.8 & 32.15 & 82 \\
\hline July & 24.6 & 39.7 & 32.15 & 70 \\
\hline June & 22.1 & 36.3 & 29.2 & 67 \\
\hline May & 17.7 & 29.7 & 23.7 & 55 \\
\hline April & 12.6 & 24.6 & 18.6 & 40 \\
\hline March & 8.9 & 18.2 & 13.55 & 32 \\
\hline February & 5.9 & 14.7 & 10.3 & 18 \\
\hline January & 3.2 & 11.1 & 7.15 & 20 \\
\hline
\end{tabular}

Table (2): Broiler production and consumption in Duhok.

\begin{tabular}{|c|c|c|}
\hline Year & $\begin{array}{c}\text { Current Production } \\
\text { (kg/year) }\end{array}$ & $\begin{array}{c}\text { Person consumption } \\
\text { (Kg/year })\end{array}$ \\
\hline 2013 & $1,460,000$ & 13.7 \\
\hline 2018 & $25,470,703$ & 23.9 \\
\hline
\end{tabular}

Table (3) Farms specification of research locations

\begin{tabular}{|c|c|c|c|c|c|c|c|c|c|c|c|}
\hline & Semel & $\begin{array}{c}\text { Shek- } \\
\text { han }\end{array}$ & Kujur & $\begin{array}{c}\text { Zawi- } \\
\text { ta }\end{array}$ & $\begin{array}{c}\text { Sar- } \\
\text { sink }\end{array}$ & $\begin{array}{c}\text { Mangea- } \\
\text { shike }\end{array}$ & Kura & $\begin{array}{c}\text { Barda- } \\
\text { rash }\end{array}$ & Zakho & Amedi & Akre \\
\hline System & close & close & close & close & close & close & close & close & close & close & close \\
\hline $\begin{array}{c}\text { Market } \\
\text { day }\end{array}$ & 50 & 48 & 48 & 52 & 50 & 50 & 48 & 48 & 50 & 53 & 52 \\
\hline $\begin{array}{c}\text { Con- } \\
\text { struct } \\
\text { metal }\end{array}$ & $\begin{array}{c}\text { Bloc } \\
\mathrm{k}\end{array}$ & Block & $\begin{array}{c}\text { Bloc } \\
\mathrm{k}\end{array}$ & $\begin{array}{c}\text { Bloc } \\
\mathrm{k}\end{array}$ & Block & Block & $\begin{array}{c}\text { Bloc } \\
\mathrm{k}\end{array}$ & Block & $\begin{array}{c}\text { Bloc } \\
\mathrm{k}\end{array}$ & $\begin{array}{c}\text { Bloc } \\
\mathrm{k}\end{array}$ & $\begin{array}{c}\text { Bloc } \\
\mathrm{k}\end{array}$ \\
\hline $\begin{array}{c}\text { Depth of } \\
\text { litter } \\
\text { (cm) }\end{array}$ & 5 & 5 & 5 & 5 & 5 & 5 & 5 & 5 & 5 & 5 & 5 \\
\hline
\end{tabular}




\section{2-1-3- Data Analysis:}

To determine energy requirements of broiler production, the total MJ (1000 bird) were calculated for each input and output elements. Standard deviations of each element were determined and recorded the coloration factor between input and output element of energy requirements of broiler production. Also, the correlations between energy variables were calculated.

\section{2-1-4-Study parameters:}

The parameters of input energy (fuel, electricity, feed and labor) and output energy (broiler meat and manure) were measured. Moreover, the economical efficiency (EE) was calculated by the ratio of sum of weighted outputs to sum of weighted inputs (Cooper et al., 2006):

$\theta=\frac{\sum_{p=1}^{P} u_{p y_{p} j}}{\sum_{q=1}^{Q} v_{q x_{q} j} j}$

Where ' $x$ ' and ' $y$ ' are inputs and outputs, ' $\mathrm{v}$ and $\mathrm{u}$ are input and output weights respectively, ' $q$ ' is the number of inputs $(\mathrm{q}=1,2, \ldots$ ,Q); ' $p$ ' is the number of output

\section{3-Results and Discussion:}

\section{3-1-Input energy at winter:}

The inputs energy of broiler production during winter is presented in Table (4). The highest value for the standard deviation was observed with the fuel, feed than electricity, which were $35763.6,1434.3$ and 6435 , respectively, while the input energy of labor was the lower value 1.02. The highest fuel consumed at Semel region that was $100620.70 \mathrm{~L}(1000$ birds $^{-1}$ ), while Kura region was obtained the mixmum feed at Duhok province which was $66645.34 \mathrm{~kg}$ (1000 birds $^{-1}$ ), comparing with closely conditions of Iranian model, this value of fuel consumption is higher than which found by (Heidari et al, 2011). Moreover, the highest electricity was observed at Sarsink region $16488.78 \mathrm{kWh}\left(1000\right.$ birds $\left.^{-1}\right)$, this area is one of coldest area at Kurdistan region, so the farm consume high electricity to keep and control farm conditions. Finally, the maximum labor energy was recoded at Kujur area that it was $127.76 \mathrm{hr}\left(1000\right.$ birds $\left.^{-1}\right)$, this lower value of labor is agreement with results found by (Toghyani, 2011). Generally, this results indicated that even with high petroleum production, still the fuel energy was the highest value of input broiler production in Duhok and Kurdistan region. This result may due to the limit and insufficient support from the local governments to the private producer. Furthermore, regarding to the mountain concepts of these locations and style of farm construction, winter is one of the harsh and snowing season in Duhok. Due to these conditions, the private producer couldn't produce during December and January months. 
Table (4): Input Energy (MJ/1000bird) at winter season.

\begin{tabular}{|c|c|c|c|c|}
\hline Locations & $\begin{array}{c}\text { Fuel } \\
(\mathbf{~ l ~})\end{array}$ & $\begin{array}{c}\text { Feed } \\
(\mathbf{K g})\end{array}$ & $\begin{array}{c}\text { electricity } \\
(\mathbf{k W h})\end{array}$ & $\begin{array}{c}\text { Labor } \\
(\mathbf{h r})\end{array}$ \\
\hline Semel & 100620.70 & 62311.40 & 14534.40 & 125.70 \\
\hline Shekhan & 95540.67 & 65310.40 & 15345.70 & 124.57 \\
\hline Zajur & 98567.40 & 65450.56 & 16445.45 & 127.76 \\
\hline Sarsink & 98445.88 & 65432.33 & 16488.78 & 126.55 \\
\hline Kura & 99667.45 & 66645.34 & 15567.45 & 125.56 \\
\hline Mangeashike & 98678.56 & 65456.34 & 14899.56 & 124.56 \\
\hline Bardarash & 974566.56 & 64489.87 & 14345.33 & 125.88 \\
\hline Zhako & 98232.77 & 65455.88 & 14567.66 & 124.55 \\
\hline Amedi & 98556.88 & 65554.34 & 14778.56 & 125.88 \\
\hline Akre & 98845.45 & 66456.34 & 14877.66 & 124.88 \\
\hline Mean & 97456.6 & 64489.8 & 16789 & 125.46 \\
\hline STD & 35763.6 & 1434.3 & 6435 & 1.02 \\
\hline & & & & 1534.45 \\
\hline
\end{tabular}

\section{3-2- Input energy at summer:}

The inputs energy of broiler production during summer are shown in Table (5). The highest value of standard deviation was observed with fuel, feed than electricity, which were 910.83, 1023.84 and 457.61, respectively, Semel region consumed the highest fuel which was 98620.70 (1000 birds ${ }^{-1}$ ), semel is one of the suburb of duhok district and national electricity is not stable. To this effect, this farm consume high fuel in both seasons to compensate the insufficient suppler of electricity. Whereas the minimum fuel consumption was 95348.56 L (1000 birds $\left.^{-1}\right)$ which observed at Mangeashike region. The maximum consumed feed was
$66895.38 \mathrm{~kg}\left(1000\right.$ birds $\left.^{-1}\right)$ at Kura region, while Akre obtained the higher electricity which was 14823.66 $\mathrm{kWh}$ (1000 birds $\left.^{-1}\right)$ and this result may due to the Akre area which is $1400 \mathrm{~m}$ higher sea level, and even during summer is cold so it need more electricity. The minimum input energy was observed for labor with STD 0.46 which was less than input energy of labor during winter season. From the obtained results, it can be calculated that during summer the fuel element had greatest value as well as during winter, while the input energy of feed recorded higher value at summer compared with winter season. 
Table (5): Input energy (MJ/1000 bird) at summer season.

\begin{tabular}{|c|l|c|c|c|}
\hline Location & \multicolumn{1}{|l}{$\begin{array}{c}\text { Fuel } \\
\text { ( L ) }\end{array}$} & \multicolumn{1}{c|}{$\begin{array}{c}\text { Feed } \\
\text { (Kg) }\end{array}$} & $\begin{array}{c}\text { electricity } \\
\text { ( kWh) }\end{array}$ & $\begin{array}{c}\text { Labor } \\
\text { ( hr) }\end{array}$ \\
\hline Semel & 98620.70 & 63312.40 & 14234.20 & 124.30 \\
\hline Shekhan & 95540.67 & 66310.65 & 13325.30 & 124.33 \\
\hline Kujur & 95580.40 & 65456.56 & 14345.45 & 125.70 \\
\hline Zawita & 96552.54 & 66392.28 & 14334.45 & 124.60 \\
\hline Sarsink & 95445.23 & 65892.35 & 14455.78 & 125.50 \\
\hline Kura & 95667.45 & 66895.38 & 13457.45 & 124.50 \\
\hline Mangeashike & 95348.56 & 65456.34 & 14233.56 & 124.56 \\
\hline Bardarash & 95560.56 & 64489.87 & 13432.33 & 125.81 \\
\hline Zhako & 96238.77 & 65455.88 & 14211.66 & 124.51 \\
\hline Amedi & 96566.80 & 65554.34 & 14233.50 & 124.81 \\
\hline Akre & 95845.30 & 66456.34 & 14823.66 & 124.80 \\
\hline Mean & 96127.65 & 65502.77 & 14107.67 & 457.61 \\
\hline STD & 910.83 & 1023.84 & 124.42 & 0.46 \\
\hline
\end{tabular}

\section{3-3-The output energy:}

The output energy of broiler production presented in Table (6). The Standard deviation of output broiler was recorded 0.61 , while the standard deviation of the output of manure was 0.02. From Ta- ble (5) the output energy of boiler during summer season was $(8.22 \%)$ higher than winter season, while the output of manure during winter was $(12.9 \%)$ higher than summer season.

Table (6): Output Energy Mj (1000bird).

\begin{tabular}{|c|c|c|}
\hline \multirow{2}{*}{ Season } & \multicolumn{2}{|c|}{ Output Energy } \\
\cline { 2 - 3 } & Broiler(Kg) & Manure(Kg) \\
\hline Summer & 11.45 & 0.31 \\
\hline Winter & 10.58 & 0.35 \\
\hline Means & 11.01 & 0.33 \\
STD & 0.61 & 0.02 \\
\hline
\end{tabular}

3-4-Economical Efficiency (EE):

The economical efficiency of broiler farm production are shown in Figure (1). The highest EE during summer season was observed at Mangeashike region, where the lowest value was less than the optimum region in Duhok by $12.35 \%$. This scattering on EE at different regions may be due to the unclear of offcial specification of initial construction specially that all these farms were private. For the winter season, Kujur farms recorded the optimum EE which was 0.86 , whereas the minimum efficiency was 0.79 at Bardarash region and this value less than the highest efficiency by $8.1 \%$. The 
winter season for Duhok farms was harsh regarding to the level of snow and the insufficient of wall isolation on $80 \%$ of farms that we investi-
gated.Logically this will lead to the limitation of the production during winter at Duhok Province.

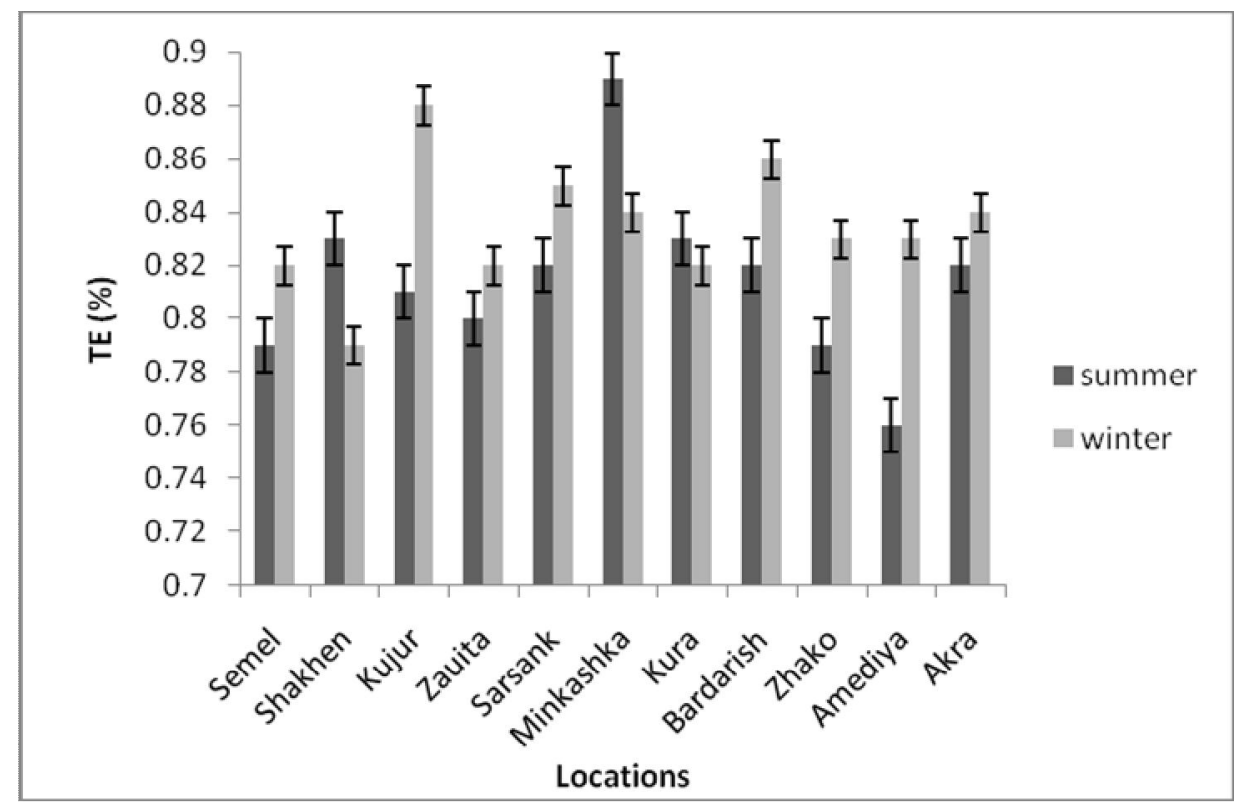

Figure (1) Economical efficiency for broiler farms.

3-5- Percentage of Input energy:

The percentage of input energy elements can be seen in Figure (2). The highest value observes with fuel that was $54.5 \%$ and $54.6 \%$ during winter and summer season, respectively, while the lowest value of input energy for labor which was $0.1 \%$ and $0.2 \%$ during winter and summer season, respectively. Moreover, the electricity was consumed energy about $9.4 \%$ during winter, while summer season was recorded $8 \%$, which it was less than winter seasons by $14.89 \%$, these results are similar to what found by (Heidaria,2011; Qotbi Ali et al., 2011). The summer season had the highest feed consumption
$(37.2 \%)$, while the lowest value was36\% which observed during winter with a decrease of $3.2 \%$ than summer consumption. The highest input was observed with fuel, electricity and feed. From this result, the fuel was consumed about $50 \%$ from the total input energy and this may be due to high demined of fuel for heating, ventilation as well as lighting, one of the reasons of high fuel consumed was the limit of national electricity which provides for $12 \mathrm{hr}$ daily and the rest will driving by diesel generations. This frequently level of energy input requirements are agreement with data optioned by (Esmaei et al, 2013), but still or input is higher than Iranian and international model. 


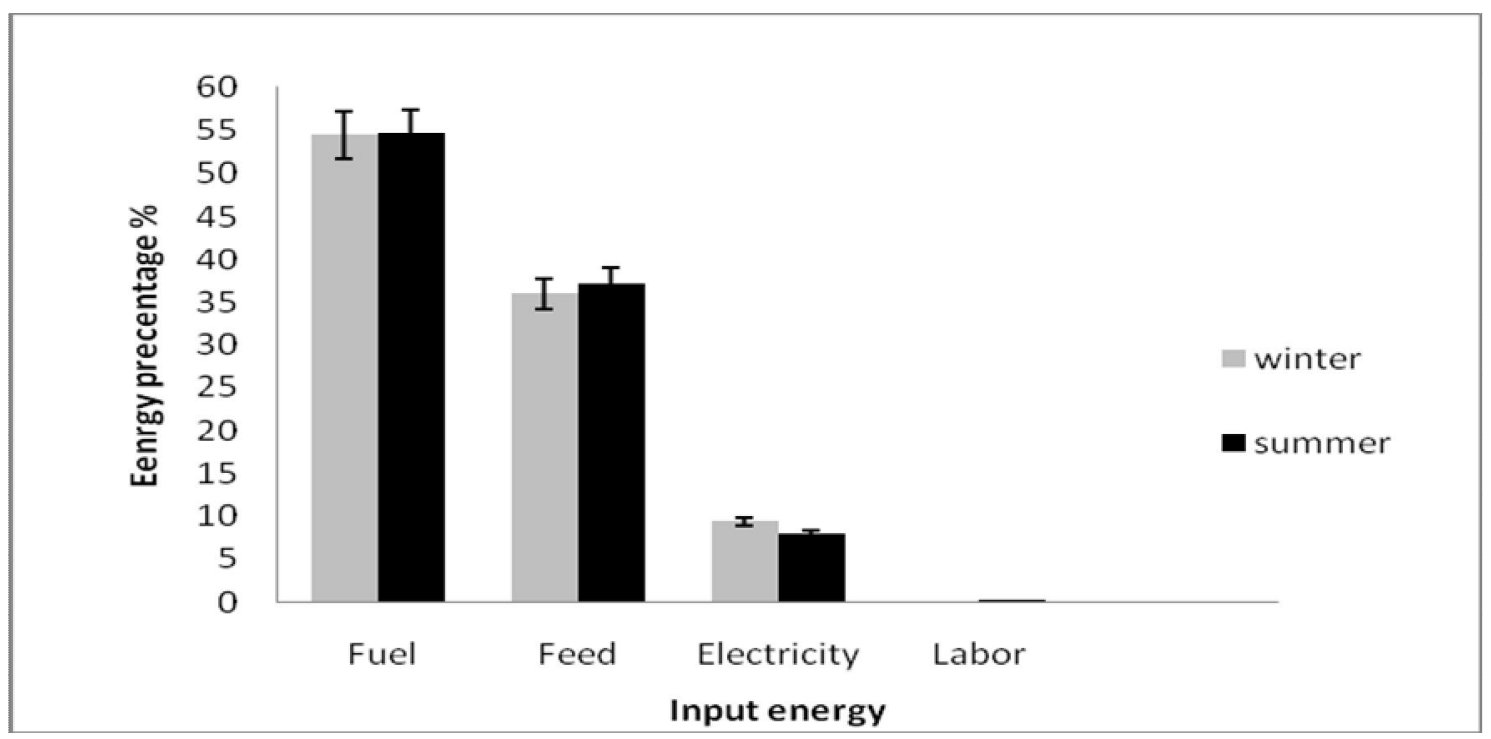

Figure (2): Input energy percentage.

3-6- Regression Model: The regression model of input energy requirements in Duhok province can be seen in Figure (3). The results indicated high positive correlation (0.982) between elements of energy and the percentage of total inputs. From the question, it can observed sample first class correlation and each input element can related with total input energy in linear relation. This model didn't fitted latterly with other researcher model such as (Costa and
Houston, 2006., Zuidhuf, 2009), the reason behind this could due to the elements ofinput power that we use is different from other previous researcher and this is the first trial to determine energy requirement in Kurdistan region. The farms of Duhok should follow standard instruction of constructed broiler farm and dramatically this will reduce the total Mj for input energy.

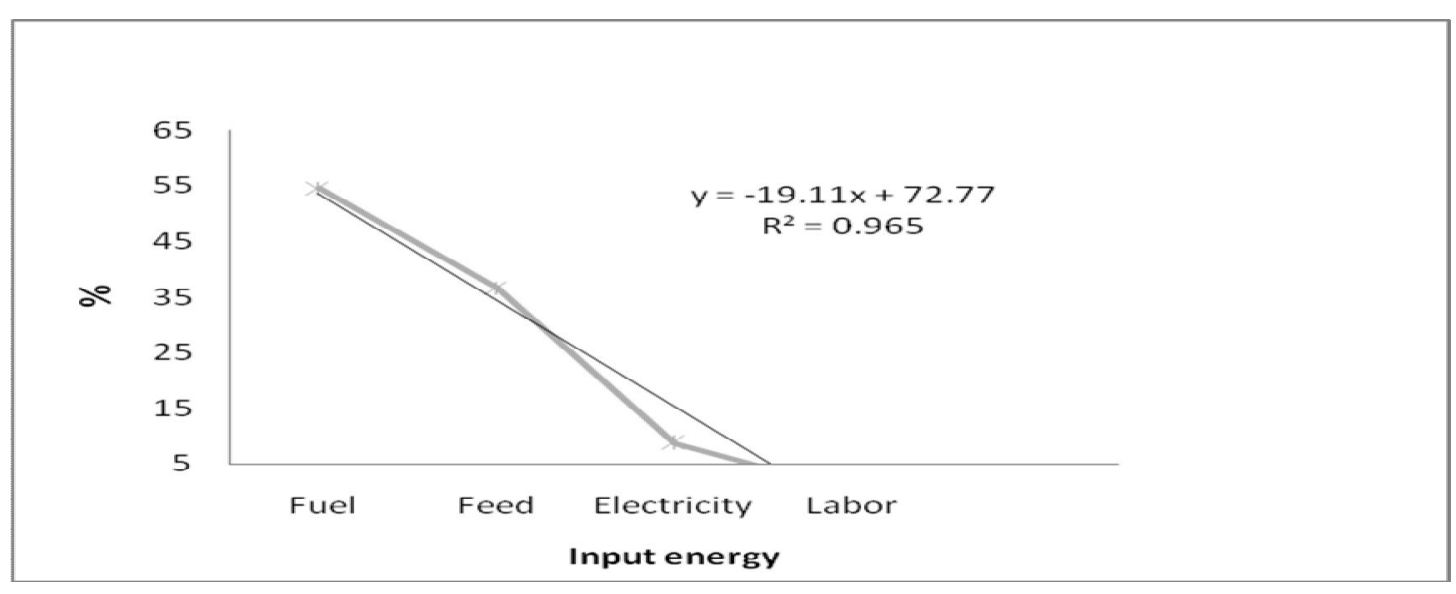

Figure (3): Regression model 
3-7-Correlation between energy inputs of broiler production:

Average capacity of surveyed farms in Duhok was 12300 birds; the average meat production of farms was $2640 \mathrm{~kg}$ (1000bird $\left.{ }^{-1}\right)$. Total energy used in input operations during summer and winter of broiler production was 175878 and 178859 MJ (1000bird-1), respectively. The correlation coefficient between input energy elements used in broiler production were showed a significant negative relation between electricity and chick, electricity and feed and finally a significant negativity between labor and chick. The other input energy elements obtained showed positive correlation coefficient and this result is agree with what found by (Heidari et al, 2011). The positive correlation between fuel and other input element is due to the increased of fuel consumption with increasing other input values, while the negativity between feed and electricity may be relate to the famer purchase the feed staff from local marketing and they didn't prepare at their one farms.

Table (6): Correlation coefficient between input elements

\begin{tabular}{|l|c|c|c|c|c|}
\hline & Chick & Fuel & Feed & Electricity & Labor \\
\hline Chick & 1.00 & & & & \\
\hline Fuel & 0.05 & 1.00 & & & \\
\hline Feed & 0.15 & 0.04 & 1.00 & & \\
\hline Electricity & -0.07 & 0.08 & -0.06 & 1.00 & \\
\hline Labor & -0.15 & 0.28 & 0.06 & 0.45 & 1.00 \\
\hline
\end{tabular}

\section{Conclusion:}

This study was conducted to measure the energy requirements of broiler production and for improving the energy use in the broiler production at Kurdistan region. The total input energy at summer was $175878 \mathrm{Mj}$ (1000 bird $^{-1}$ ), while at winter the input energy was $178859 \mathrm{Mj}(1000$ bird $\left.^{-1}\right)$. The output energy of broiler production during summer season was $(8.22 \%)$ more than winter production, while the output of manure during winter was higher than summer about (12.9\%). The correlation coefficients showed negative relation as well as positives relation of input energy requirements. The broiler production farms in Kurdistan region have high consumption of fuel and power as well as low output income for winner. To this effect, additional follow and support form local governments will assist on improve these conditions

\section{References:}

Adonis, R.C., Jesusa M.V., Marionne Jessa, Y.M. and Ma. C. S. (2009). Optimizing Harvest dates in philippine commercial poultry farming. International Multiconference of Enge*neers. II: 978-988.

Alrwis, K.N. and Francis, E. (2003). Technical efficiency of broiler farms in the central region of Saudi Aradia: Stochastic Frontier Approach. Research bulletin, 5-34.

Atilgan, A. and Hayati, K. (2006). Cultural energy analysis on broilers rearedin different ca- 
pacity poultry houses. Italian Journal of Animal Science, 393-400.

Costa, E. F and Houston, J. A. (2006). An interactive decision model integrating broiler production and processing responsiveness to consumer and producer prices, Economic Conference, Gold Coast, Austrilla, 2328.

Cooper, W.W., Seiford L.M. and Tone, K. (2006). Introduction to DEA and its uses with DEASolver software and references, Springer, New York.

Eliseo Bustamante, E. A. (2013). Exploring ventilation efficincy in poulty building. Energies 6: 2605-2623.

Esmaei, M.O., Aliraze K. and Payam J. (2013). Froecasting the thermal load for implementing solar energy in a model poulty house. Journal of Agricultural Engineering \& Biotechnology. 1(2): 30-36.

Heidari, M.D., Omid, M and Akram, M. (2011). Energy efficiency and econometric analysis of broiler production farms. Eenrgy. 36(11): 6536-6541.

Heidaria, M.E.A.

(2011). Optimization of energy consumption of broiler production farms using data envelopment analysis approach. Modren Appiled Science. 5(3): 1913-1852.

Kizilaslan, H. (2009). Input-output energy analysis of cherries production in Tokat province of turkey. Applied Energy, 86, 1354-1358.

Lima, K., D. Moura, D.j., Carvalho, TMR., Buneo LGF and Vercellinao, RA. (2011).
Ammonia emissions in tunnelventilated broiler houses." Revista Brasileira de Ciência Avícola 13: 265-270.

Mariano, P.E.A. (2007). Evaluation of a simplified model for estimating energy balance in broilers poeduction housing. Revista Barasileira de Engenharia Agricola Ambiental, 11(5): 532-536.

Ojo, S.O. (2003). Productivity and technical efficiency of poultry egg production in Nigeria. International Journal of Poultry Science, 2(6), 459-464.

Qotbi Ali, S.N., Ahmedauli, O., Rahmatnejad, E. and Abbasinezhad, M. (2011). Investigation of Poultry housing capacity on energy efficincy of broiler chickens production in tropical areas. African Journal of Biotechnology, 10(69): 15662-15666.

Santos, C. and Falconi, F. (2007). Relationship between ecological concepts and biosafety in broiler breeder farms. Revista Brasileira de Ciência Avícola 9: 151-155.

Toghyani, M.M.A.M. (2011). Modeling daily feed intake of four strains of Broiler chicks. Jounal of Animal and Veterinary Advcnes 10 (9): 1140-1140.

Yiqun Pan, M.Z.A.G.W. (2009). Whole building energy simulation and energy saving potential analysis of a large pubilc building. Eleventh International IBPSA Conference,P:32-38.

Zuidhof, M.J.(2009). Nonlinear effrct of diet on boriler porduction Arkansas Nutrition Conference, P:55-61. 


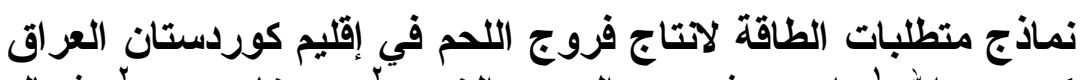

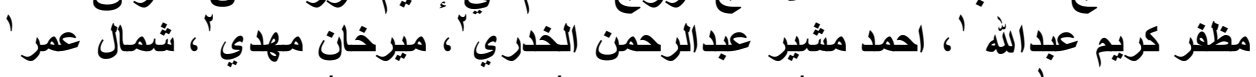

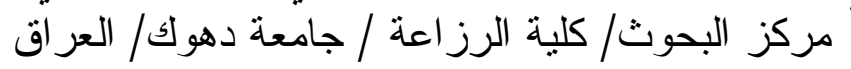

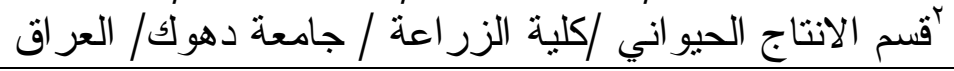

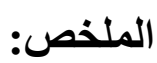

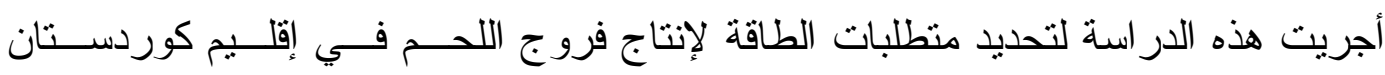

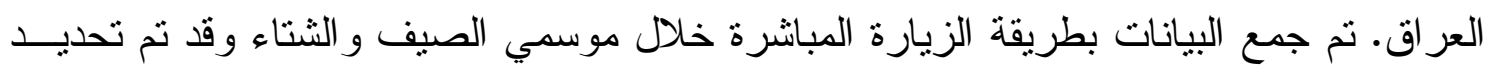
111 مزرعة موزعة على كل مناطق التربية في محافظة دهوك كنموج لكوردستان. كان معـدل

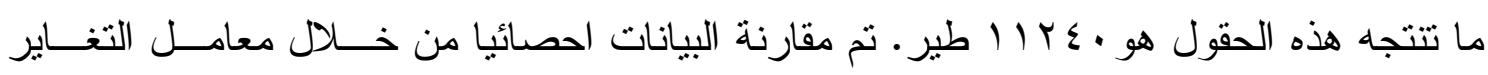

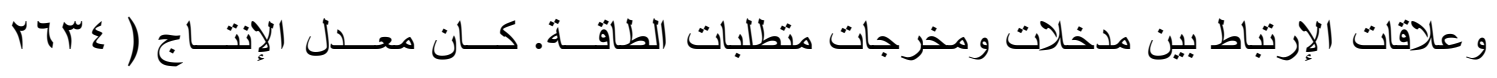

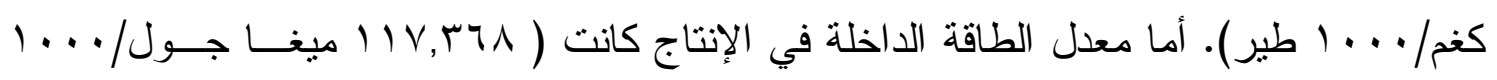

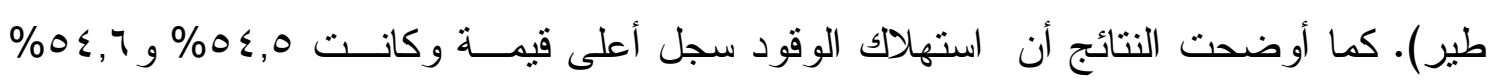

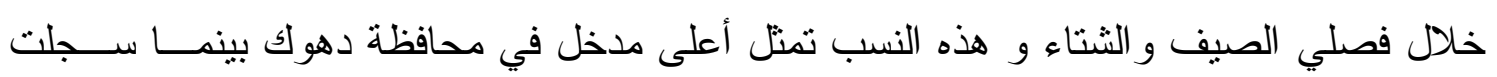

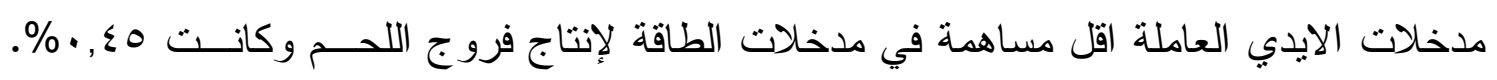

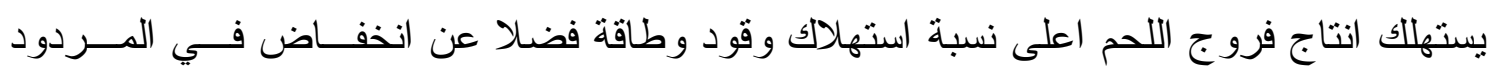

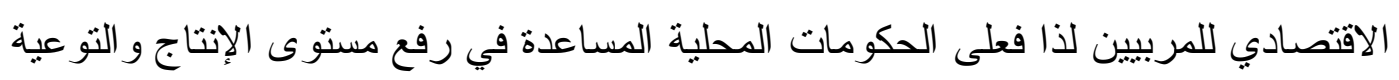
رموز دالة: منطلبات الطاقة، فروج اللحم، انتاج الدواجن، دهوك 